Article received on September $29^{\text {th }} 2014$

Article accepted on February $24^{\text {th }} 2015$

UDC: 7.01

14 Бадју А.

\author{
Bojana Matejić* * \\ University of Art, \\ Faculty of Fine Arts, Belgrade
}

\title{
VERGEBLICHES WARTEN? BADIOU, EVENT, AND HUMAN EMANCIPATION IN MUSIC
}

\begin{abstract}
The polemic on waiting for human emancipation in music belongs to the modern aesthetic plane, where Adorno's and Heidegger's manuscripts occupy a specific place. However, while Heidegger's ontology of the waiting implies waiting for the metaphysics of presence (Will), Adorno maintains that music should rather express "waiting in vain" (vergebliches Warten) by its spatio-temporal structuration, given that "after Auschwitz" philosophy with metaphysical assumptions is no longer possible. In the light of Adorno's modern interpretation of waiting in vain, my aim is to examine Badiou's conception of the Event-Subject in music. The thesis of this paper is that Adorno's concept of waiting in vain expresses defeatism of the known (perseverance-of-self) - which, due to its own character of filled affect of disappointment, does not leave time-space for newness. On the trail of Badiou's ontology of subtraction, I oppose the conception of affirmative, non-eschatological, chiliastic expectation ("surplus of waiting") to the passive waiting in vain in music.
\end{abstract}

Keywords: Vergebliches Warten ("waiting in vain"), non-eschatological, chiliastic expectation, Event, Subject of music, Wagner, Adorno, Badiou

* Author contact information: bojana.matejic@outlook.com 
The question: "A new world? Yes, but when?", which Badiou poses in his eponymous essay ${ }^{1}$ is a question about the gap between that which is "no more" or, rather, between dissatisfaction with the existing state of art (the art world) and the kind of art that is (eagerly) awaited - real art, its truth, real life, which is still not here. It concerns an emanation of the conflict between the empirical condition of the existing art world and its truth. Badiou begins from what is in his view an utterly modern issue, one that accompanied avant-garde art throughout the $20^{\text {th }}$ century. He notes that throughout the $20^{\text {th }}$ century, the politics of emancipation, that is, the idea of revolutionizing man was closely followed by a "lurking figure", in the domain of art as well as in other spheres. This is a rather specific concept of waiting, which the new millennium has, for all intents and purposes, "rejected" and proclaimed, on the one hand, "futile" and, on the other hand, "terrorist". Waiting or, rather, "lurking", says Badiou, was meant to maintain "pure vigilance". However, modern, poetic waiting above all entailed preserving the threshold, keeping waiting (as I will demonstrate regarding Adorno) by maintaining indifference about that which may or may not occur. Because those who wait are those who may still have hope.

So, departing from Brecht's text "Das Proletariat ist nicht in einer weißen Weste geboren" (The Proletariat Wasn't Born in a White Vest, 1932), Badiou discusses the modernist obsession with the discrepancy between the agonist, nihilist, and antagonist ${ }^{2}$ avant-garde tendency of destroying art (exposing the Real) and its "new" - its "beginning": "When will the new finally come? Is the new already at work, can we already discern its development? Or are we still spellbound by what is merely an old form of the new, a 'new' that is all too ancient because it still prisoner to destruction? Consequently, the question is 'When?". ${ }^{3}$ In the present context, I would point to Marx's key claim in his "Letters to Ruge": it is necessary to "develop the true reality" "from the forms peculiar to existing reality" ${ }^{4}$ because all emancipatory, critical, avant-garde art rests on the assumption of a fundamental gap between the existing condition, critiqued from the perspective of its inherent, immanent conflicts, that is, antagonisms, and its immanent opposite - the truth or, rather, in the spirit of early

\footnotetext{
1 Alain Badiou, “A New World? Yes, but When?", in: The Century, Cambridge, MA, Polity Press, 2007, 44.

$2 C f$. Renato Pođoli [Renato Poggioli], “Agonizam i futurizam”, in: Teorija avangardne umetnosti, Belgrade, Nolit, 1975, 95-111.

3 Alain Badiou, “A New World?", op. cit., 44.

4 Karl Marx, "Marxova pisma Rugeu", in: Rani radovi, Zagreb, Naprijed, 1967, 52. Available in English at https://www.marxists.org/archive/marx/works/1843/letters/43_09.htm (accessed 24 August 2016).
} 
Marx, the realization of the true man, of true life, of life that one is born with. I believe that this claim, though following the trail of neo-Marxist interpretations, forms the basis of the $20^{\text {th }}$-century avant-garde maxim of the conjunction of art and life.

\section{The Event, the Truth, and the Subject of Music}

The truth of/in art, in early Marx and Badiou alike, with all the contradictions of that notion in mind, does not denote the present condition of art, but nor is it an entity outside of the given reality. However, what is awaited is the realization of the truth in the existing art world and work of art. Although Marx believes in the total emancipation of society, that is, of art and culture, as well as of man from man by way of art and culture from the perspective of thinking the necessity of radical change, Marx certainly does not assume an authentic source of truth ("human nature", "essence", "the true man") that would be a direct negation of the existing, static reality. In this light, the existing art world should be viewed as a specific historical given and its immanent truth as its historical moment, as something that is historically contingent and cannot be a moral postulate in the spirit of Enlightenment ideology, which Marx himself spurned. Ultimately, I believe that that is what might be related with Badiou's position: the event of true art, as a generic truth procedure, happens in a certain place in a given situation, so that the place may be localized (a new name: serialism, dodecaphony, Cubism, Dada, etc.):

Truth is here the generic set of the evental consequences of these mutations of art. It's a sequence of a specific art. There is, for example, a truth of the resources of sound discovered by serial music. ... the evental mutation renders the truth of the sequence that precedes it. It is absolutely evident, for example, that Schoenberg's atonal proposition yields the truth of the point reached by tonality itself. In reality, Schoenberg produces, in a certain sense, the truth of Wagner or Mahler. The latter appear as figures of tonality's decomposition at a juncture where tonality could no longer continue as such. This impossibility of continuing is sealed or validated by the new musical creation. The event opens up in this way the possibility of understanding the very situation in which it is produced. Dodecaphonic, then serial, music produces a definitive truth of the whole tonal sequence at the same time as it puts an end to it. ${ }^{5}$

In Badiou's philosophical optics, the truth of art is that which is immanent to the work of art and not, as in the didactic Platonist transcendental regime of objective idealism, a normative instance imposed on art from without. Badiou

5 Alain Badiou, with Fabien Tarby, Philosophy and the Event, Cambridge, MA, Polity Press, 2013, 70-71. 
clearly says as much in the opening piece in his Handbook of Inaesthetics, ${ }^{6}$ when considering the four historic-aesthetic dispositives of art: didactic, romantic, classical, and (avant-garde) didactic-romantic, and when he proposes a new perspective of thinking art as a "pedagogical practice" that has coincided, ever since classical ancient, that is, Platonic thought, with the modern problem of human emancipation in the field of art. Let me briefly digress to point out that to a significant degree, such a perspective of understanding the modalities of emancipatory art became the subject of the vulgar-materialist representational aesthetics of orthodox Marxism during the $20^{\text {th }}$ century, which was, as is well known, most radically epitomized in the ideology of socialist realism. Badiou's novel proposition of art as a generic truth procedure introduces thinking the truth of art as singular and immanent, which may be reduced to the following three statements: 1. truth is immanent to the artwork and and to art as a generic procedure;

2. art is coextensive [suprotežna] with the truths it produces;

3. art is not a means of expressing truths imposed from without.

In Badiou's conceptual matrix, another name for artistic truth is "the trace of the event" of art and in the context of music, say, Schoenberg's new music, which is Badiou's favourite example, the trace or truth of the event implies that element in Schoenberg's pieces, from so-called atonal expressionism, which may be discerned in terms of an abstract formula of organizing comprising 12 constituent notes. "Where there used to be the system of scales and the basic harmony of the tonal system", Badiou says, "we now have the free choice of a succession of distinct notes, fixing the order in which these notes should appear or be combined, a succession that is called a series". ${ }^{7}$ As we may see, it is a specific, serial type of

${ }^{6}$ In Badiou's philosophical optics, aesthetics should not be viewed in terms of its modern definition as the philosophical discipline that deals with "lower sensory perception" - as that which is somehow "primary" and "superior" in relation to art. On the contrary, Art is one of the three remaining generic truth procedures (politics, love, science), in other words, a sphere that is "itself capable of truth" and that conditions aesthetics (philosophy). Therefore, this is neither aesthetics in the classical, traditional philosophical sense, nor anti-aesthetics, but inaesthetics as the kind of thinking art that is conditioned by its truth, based on "intra-philosophical effects". Art as thought or, more precisely, the truths that art as thought activates, are irreducible to other truths: scientific, political, or truths of love. That means that art, as a singular regime of thought, is not reducible to philosophy - it cannot be identified with philosophy, theory, or any other cognitive sphere, because art and the work of art possess their own sui generis.

7 Alain Badiou, "Une variante musicale de la mètaphysique du sujet", in: Logiques des Mondes. L'Être et l'Événement, II, Paris, Éditions du Seuil, 2006, 90. Cf. Alain Badiou, "A Musical Variant of the Metaphysics of the Subject", Parrhesia. A Journal of Critical Philosophy, No. 2, 29-36. 
organizing the 12 tones of the chromatic scale, no longer subject to the hierarchy of tonal construction and the laws of classical harmony, but "treated equally", according to the principle of succession. Such a serial type of organization directs tones to one another, "to their reciprocal relations in a determined acoustic space". Moreover, Badiou asserts that the truth of the event in the context of music should not be mistaken for dodecaphonic or serial music as such, but that it denotes a certain novelty that is inscribed in the existing musical discourse, in its traces, which is, according to Badiou, easiest to express with the proposition that there may be an organization of tones as that which determines the musical universe on the basis subtracted [la soustraction] from classical tonality.

In Badiou's view, the truth/s of art is/are conditioned by the event/s, which is nothing but a disappearing separator ${ }^{8}$ - an un-temporal moment that separates an anterior state of an object (the state of art and/or form of a work of art) from a future state. Badiou's argumentation regarding the possibility of affirming the subject of art "from poststructuralism" involves proposing the affirmation of the subject of art in terms of temporality - the time of "stitching together" artistic truth/s, which is/are the trace/s of the event/s, which, however, no one even knows when it/they took place, bearing in mind that this concerns the exempted/exceptional place of its/their occurrences - although that place may be localized - and the body of art that is the artwork itself, its materiality, "its fact" or, as Badiou would put it, that which "carries" the truth toward its "appearance".

The subject of art, I must note straight away, is not another name for the individual; rather, it denotes an artistic sequence/configuration, a set comprising a multitude of artistic truths, wherein they are "verified". Badiou does not mean this proposition of the subject of art in terms of the tradition of avant-garde art, which would itself be oxymoronic, or, in the context of this analysis, in terms of the tradition of avant-garde music, but as a specific multiple generic sequence (which means, paradoxically, that it is temporally limited, but only in relation to a given historical situation, although it simultaneously belongs to an artistic configuration as a subject of art, which is endless and trans-historical, because it can infinitely expand and proliferate across both time and space and thus come to encompass worlds that are temporally and spatially wide apart (epochs, histories, nations, etc.), wherein emancipatory change in art by way of subjective temporality - of time as a subject of art - unfolds diagonally: on the one hand, this is subjection time [vreme subjektivacije], which enables separating individual events, so that each event may be discerned in its own singularity (an

8 Antonio Calcagno, Badiou and Derrida: Politics, Events and their Time, London, Continuum, 2007, 75. 
artistic sequence within a particular world); on the other hand, it is subjective time, which is subjective intervention as such, as that which resolves the event (an infinite artistic configuration in a trans-historical interval), i.e. as that which allows the event to be "recognized". In fact, this concerns "fidelity" (fidélité) in a singular event, as the "undecidable multitude". ${ }^{9}$ However, this singular change is neither ontological nor transcendental. The event "knows" no time.

Therefore, one should stress that this subjective and subjecting time is not another name for history, although, paradoxically, Badiou argues that "there is only a history of the eternal, because only the eternal proceeds from the event". ${ }^{10}$ This is a good time to cite another, even more paradoxical claim of Badiou's, one that he explains in a number of instances and which appears to be in contradiction with the preceding claim: "there is no history". ${ }^{11}$ The first paradoxical claim one should rather view in line with Badiou's argumentation with which he seeks to defend it and which belongs neither to the system of classical metaphysics, where eternal truths exist regardless of any historicity, nor to post-philosophical relativism, which claims that there are no (eternal) truths, but only discursive constructs and utterances inscribed in a (given) historical-cultural context, thereby reducing the notion of truth to particular instances of making utterances in relation to a given field of reference. In other words, there is no history with a capital " $\mathrm{H}$ " in terms of a metaphysical totality, that is, a totality that might be recognized in the tradition of philosophical thought from Hegel to Marx, nor is there a mere plurality of histories where truths appear only as effects of a given cultural-historical inscription. Artistic truths are therefore eternal precisely because they are historical:

They insist in history, tying together temporal segments across the centuries, always unfolding more profoundly the infinity of their potential consequences, through captivated subjects, separated sometimes by distant epochs, but all equally transfixed by the urgent eventality that illuminates their present. ${ }^{12}$

To wrap up this analysis: in Logics of Worlds, volume two of his major work, Being and Event, Badiou attempts to answer the question of how (artistic) truth appears in the world, in other words, to solve the problem of "linking" being and "being-there" (existence) that unfolds in the (particular) world on a non-

9 Bojana Matejić, "Emancipation and Other in Art: Derrida alongside Badiou", in: Nika Škof and Tadej Pirc (eds.), It's Not All Black and White: Perspectives on Otherness, Gornja Radgona, A priori, 2013, 317.

10 Quentin Meillassoux, "History and Event in Alain Badiou", Parrhesia, 2011, 12, 1.

11 Cf. Alain Badiou, Théorie du sujet, Paris, Éditions du Seuil, 1982. Cf. Alain Badiou, Logiques des Mondes, L'Être et l'Événement, II, Paris, Éditions du Seuil, 2006.

12 Quentin Meillassoux, op. cit., 4. 
essentialist and non-substantialist basis. What he means here is "worlds", to put it simply, particular historical contexts, states of situations, cultural contexts, epochs, artistic moments - for instance, one of those worlds might be music itself, comprising infinite other worlds (for example, classicism, romanticism, music theory, minimalism, etc.) - wherein a singular event, a singular change may occur and keep occurring. Each world consists of infinite other worlds and each one of those worlds is, in a sense, "historical". But that "historicity" is not a history inscribed by eternal truths. It concerns understanding the historicity of worlds as an immanent mode of temporising the inscribed into transcendental regimes within given worlds. Since there are an infinite number of worlds, which are distinguished by their transcendental horizons, Badiou may argue that there are as many "histories" as there are worlds. ${ }^{13}$ However, those histories ultimately "do not exist". A world may be an epoch, the historical context of an art (for instance, the emergence of Schoenberg's dodecaphony, bearing in mind that the truth of dodecaphony is trans-historical and trans-worldly), which means an infinite multitude of worlds and histories, which are temporally successive and synchronic, which ultimately entails that a given being or (emancipatory) truth may emerge in infinite various ways at one and the same time and in different (historical, cultural, epochal, etc.) worlds.

The subject, therefore, is not an individual but a "set" of artworks, or, rather, a "differential point in an artistic procedure". This "set" of artworks and artistic phenomena consists of artistic sequences ("contemporary" or "new" art at a given historical moment, in a given art world), which come to be incorporated in the infinite trans-historical configuration of art, inscribed with eternal truths; truths that are only artistic truths, because, in Badiou's words, "there is no truth of truth". ${ }^{14}$ In Badiou's argumentation, a work of art is neither an event, nor the truth of art. A work of art is only the body of truth, that is, a "fact" of art, "materiality" whereby art is realized as a generic procedure. In this process, the work of art itself is a "local instance or differential point of truth". The individual is a living being that is "inscribed into the subject of the sensuous" - an artistic configuration. Furthermore, the author of a work of art is not the cause of the work, but rather its "disappearing cause", because s/he is involved in the process of producing the work. Artistic truth does not emerge as an expression or reflection of the author. Finally, in Badiou's antihumanist perspective on art theory, the subject is not another name for authorship.

13 Sergei Prozorov, "Universality and Historicity", in: World Politics. Void Universalism I, New York, Routledge, 2014, 88.

14 Alain Badiou, “Art and Politics", in: Handbook of Inaesthetics, Stanford, Stanford University Press, 2005, 12. 
The subject of art is constituted at the moment when an artistic sequence/ configuration is established, which, as temporality, unfolds between change in the world and non-change of being. An artistic configuration, Badiou claims, is a generic multitude of artworks without a corresponding name, form, or reference to a genre or an "objective" period in the history of art; equally, it cannot be named or totalised on the basis of the technical dispositive of art. ${ }^{15}$ In other words, the subject of art is nothing but the subject of producing truth/s between singular change in art in a concrete situation and generic truth. ${ }^{16}$ Badiou illustrates this rather well when he argues that "Schoenberg produces ... in a certain sense, the truth of Wagner and Mahler", ${ }^{17}$ just as Picasso produces the truth of the unknown author of a wall-painting of a horse from the Chauvet cave, where a "pure form of life" 18 is realized as that which is shared (the universality of truth) in their particularities and different, historically and contextually remote worlds.

One may note that in Badiou's doctrine, the (artistic) event possesses, on the one hand, a universal dimension, at the same time, however, maintaining its particular dimension, without one excluding the other, as it happens in Hegel's conception of absolute spirit and in the artistic domain of the radicalization of the "end of art" (Aufhebung), which means that these two dimensions "meet" and in that "meeting" "verify" each other. The particular truth of a singular event always unfolds in a given historical constellation, in a given art world, in a given place (la site), "subtracted" from the classified knowledge of the existing art world and, paradoxically, partakes in subjection, a specific temporality that is nothing but a sequence of an infinite artistic configuration. In that context, the following example from Badiou may serve as a good illustration:

The history of serial music between Schönberg's Variations for Orchestra (1926) and, let's say, the first version of Pierre Boulez's Répons (1981) is not an anarchic history. It treats a sequence of problems, comes up against obstacles, ... extends its domain ... This history is coextensive with the existence of a subject (often bizarrely named 'contemporary music'). ${ }^{19}$

This kind of perspective on thinking truth in art is, conditionally speaking, rather close to Marx's, from his "Contribution to the Critique of Political Economy" (1857-59), where he argues that the difficulty in understanding the very

15 Ibid., 13.

16 Alain Badiou, The Subject of Change: Lessons from the European Graduate School, New York - Dresden, Atropos Press, 2013, 120.

17 Ibid., 71.

18 Alain Badiou, "Example artistique: chevaux", in: Logiques des Mondes, op. cit., 27.

19 Alain Badiou, Logics of Worlds: Being and Event, 2, London, Continuum, 2006, 81. 
essence of the truth of art and the work of art - he cites the example of ancient Greek art and epic - lies not so much in understanding the contingency of certain forms of artistic activity and their historical, social, and politico-economic dispositive, but the reason why all these artistic truths are "alive" for all individuals, regardless of their social status, epoch, or historical context. ${ }^{20}$

Therefore, the concept of infinite artistic configuration implies that which cannot be named, "counted", "measured", or "calculated" within the space of art in a given temporal context; at a historical juncture. Infinite artistic configuration affirms art as "subtracted" from all previous classifications and anticipations. (Artistic) truths, says Quentin Meillassoux, "cannot exist in a Heaven of Ideas: they are the result of an undecidable event and of a fidelity of subjects that attempt to investigate their world in light of it". ${ }^{21}$ What is involved in this undecidability of the event in the field of art as a generic truth procedure? Badiou's argumentation regarding the undecidability of the event refers to the way the event itself should be thought in relation to the factual state of a given situation and, most importantly, to the mode of one's own occurrence in space and time.

In fact, as I already tried to show, the event does not occur, because it is always already something that has disappeared (an un-temporal moment) at the moment of its own inscription, that is, the localization of its place, on which basis one may cognize that the event really took place. However, precisely this perspective of thinking the event of art gives rise to the dimension of the undecidability of multitude in the world, because an occurrence of that sort, in a quite indeterminate way, implies the doubt that perhaps nothing really happened, "except the illusion of novelty". ${ }^{22}$

\section{Vergebliches Warten in Music: Adorno vs. Badiou}

Following this attempt to provide a careful explication of the important points in Badiou's argumentation concerning the contingency of the subject of music and art in general on the event of truth, I can move on to the main issue: if the event, in a contingent way, "precedes" the subject of art and conditions the production of a subject that is an artistic configuration, does that imply that one should wait for events, that is, for situations corresponding to an affirmative emancipation of man, for an affirmative generic humanity? What does this affirmativity entail and in what way may pure waiting have an emancipatory dimension? How does the

20 Karl Marx, A Contribution to the Critique of Political Economy, New York, International Publishers, 1970.

21 Quentin Meillassoux, "History and Event in Alain Badiou", op. cit., 1.

22 Ibid., 3. 
human animal at all come into the possession of its own activity along the axis of recipient-author, which is, according to Hannah Arendt, in addition to work and production, a fundamental conditio humana, given that in acting and speaking man is confirmed qua man and thus emerges in "his unique diversity"? 23

It seems that this is a question that "must not be posed", because it evokes the "threat of the metaphysics of presence" of emancipatory art as concrete life, as "alive", which in postmodernist culture bears the responsibility for "Auschwitz", ${ }^{24}$ that which must happen never again. However, this question regarding the Messianic status of the conception of event in Badiou's conceptual matrix is neither unjustified, nor is it being posed here for the first time. Daniel Bensaï is one of those who, a few years ago, similarly asked: ${ }^{25}$

What exactly is an event? Aleatory by nature, the event cannot be predicted outside a singular situation, nor even deduced from that situation without some unpredictable chance operation. ... Badiou's notion of the political tips over into a wholly imaginary dimension: this is politics made tantamount to an act of levitation, reduced to a series of unconditioned events and 'sequences' whose exhaustion or end remains forever mysterious. As a result, history and the event become miraculous in Spinoza's sense - a miracle is 'an event the cause of which cannot be explained'. Politics can only flirt with a theology or aesthetics of the event. ${ }^{26}$

I am not far from agreeing with Bensaïd's position. Indeed, it seems as if individuals, recipients, creators, authors, etc. are "condemned" to wait for mysterious events that no one knows when or how they will occur, because in historical or, if you will, world terms, they happen in an utterly unpredictable fashion, without any possibility for individuals to affect them and in total disregard for individuals' vital needs at a given historical moment and in a given art world. "Badiou remains silent on this score", Bensaïd says. ${ }^{27}$ Paradoxically, doesn't this issue concern that same maxim by Marx, already mentioned above, that the true reality should be developed from the forms peculiar to existing reality? For, in proposition No. 6 in his text "Une variante musicale de la métaphysique du sujet", ${ }^{28}$ Badiou talks about the existence of two modalities of the subject: the first modality, he argues, "assumes the form of adjusting" within the old art

23 Hannah Arendt, Vita Activa, Zagreb, August Cesarec, 1991, 168.

24 Cf. Theodor Adorno, Negative Dialectics, London, Routledge, 1973.

25 Daniel Bensaïd, "Alain Badiou and the Miracle of Event", in: Peter Hallward (ed.), Think Again: Alain Badiou and the Future of Philosophy, London - New York, Continuum, 2004.

26 Ibid., 97-98.

27 Ibid. 97.

28 Alain Badiou, "Une variante musicale de la mètaphysique du sujet", in: Logiques des mondes: L'Être et l'événement, op. cit., 92. 
world; with regards to the existing art world and in that light, it entails opening a new possibility, one that is immanent to the existing art world, that is, music. The second modality examines the limitations that the art world imposes on the need for choice and in that regard, the subject's second modality is what Badiou elaborated in his Théorie des points. In the former case, Badiou argues, the subject is realized as "as an infinite negotiation with the world, whose structures it stretches and opens. In the second case, it presents itself both as a decision - whose localization is imposed by the impossibility of the open - and as the obligatory forcing of the possible". ${ }^{29}$ And yet, both modalities are conditioned by the consequences of artistic events, as Badiou clearly states in the opening sentence of his sixth proposition.

One cannot ignore the problem of thinking emancipatory music, which assumes "freedom" in music and art, that is, what Marx calls concrete, (human) generic life - elaborated and defended as the ideal of art and the politics of aestheticization especially by neo-Marxist authors - in the domains of modern philosophy, aesthetics, and art theory, comprised in interference with the theological paradigm and tradition. Didn't Badiou himself comment precisely on a situation from Christian theological discourse, the situation of St. Paul, as an object of re-reading with a view to examine the problem of a non-substantialist and non-essentialist "grounding" of universalism? It is a kind of philosophicaesthetic Messianism, which is, to put it simply, closely linked with the notion of utopia, inasmuch as the latter expresses the necessity of opening a (new) future, that which is, to use Alain Badiou's terms, present but not also included in the existing world of art.

In the context of this problem and with reference to music, what comes to mind is the entire work of Theodor Adorno, who repeatedly asserted that "after Auschwitz", modern philosophy, with its metaphysical assumptions, is no longer possible. The failure of culture, the failure of the Enlightenment project, ${ }^{30}$ and, finally, the failure of change, of man's emancipation (from man) and the need and demand for attaining autarchy in the field of art, Adorno claims, were all proven by "Auschwitz", which was allowed to happen "in the midst of the traditions of philosophy, of art, and of the enlightening sciences". ${ }^{31}$ What is the import of Adorno's claim? It concerns the question of whether metaphysics is still possible at all, which "must reflect the negation of the finite which finite-

29 Alain Badiou, Logics of Worlds, op. cit., 82.

30 Cf. Max Horkheimer and Teodor W. Adorno, Dialectic of Enlightenment: Philosophical Fragments, Stanford, Stanford University Press, 2002.

31 Theodor Adorno, Negative Dialectics, op. cit., 366. 
ness requires" ${ }^{32}$ Because, as Adorno claims, the concept of truth, following the entire trajectory of German Idealism, from Kant all the way to Marx, may be reduced to the hypothesis of "something imagined for no reason", with thought deluding itself into imagining that it possesses that which is lost (the generic quality of the humanum or, rather, the concreteness of a "living" work of art). This place of emancipated and emancipatory art, in a word, music as concrete life, as a total work of art (Gesamtkunstwerk), is the place that we eagerly await, but it is difficult to reach, because, apparently, it constitutes a Lacanian objet petit $a$, an object whose "Thing" (das Ding) resides on the other side of the pleasure principle. ${ }^{33}$ It was the desire that haunted the entire $20^{\text {th }}$ century in the domains of politics, art, science, and love, the desire to "expose the Real", to reach the place of absolute autarchy, the experience of happiness, the concrete life of a social human being in the domain of artistic acting. If we come too close to this object, whose place is "that right" to assumed concrete life, we will realize that it is not there. That is the artistic demand expressed by the entire $20^{\text {th }}$ century in the need to reach the other side of the illusion, to "reveal" the Real of art and the work of art and to localize its place. Echoing Kant, Adorno argues that precisely because we find ourselves inside and amidst the phenomenon, completely surrounded by it, that "inside" and "amidst" prevents us from seeing: "the person who is happy is too close to it to be able to have any standpoint towards it within consciousness". 34

"There is", Adorno assures us, "an extremely deep constellation between metaphysical experience and happiness", "something within objects and, at the same time, remote from them". ${ }^{35}$ If the very feeling of happiness is still possible by means of finding somewhere something like the concrete life of art, then it is possible, Adorno argues, because it drives the subject of such an experience to equate "surviving traces of the life" with concrete life. Precisely for that reason, Adorno argues that "the form in which metaphysical experience still manifests itself with any compelling force today is not that which has made itself suspect as a sphere of Romantic wishing, but is the experience which leads to the question: Is that all?". ${ }^{36}$ Adorno maintains that the form wherein metaphysical experience is "revealed" to us most intensely is the situation of "waiting" (Warten).

\footnotetext{
32 Ibid., 392.

33 Stefan Köchel, "Vergebliches Warten: Die Kunst in der Kultur", in: Das Gesetz des Realen: Lacan, Merleau-Ponty, Adorno, Vienna - Münster, MLit Verlag, 2013, 169.

34 Theodor Adorno, "Metaphysical Experience: Fruitless Waiting", in: Metaphysics: Concept and Problems, 2002, 140.

35 Ibid.

36 Ibid., 143.
} 
In Negative Dialectics, Adorno makes an extremely important claim, assuming a distinction between "waiting in vain" or "idle waiting" (vergebliches Warten) and expectation, arguing that idle waiting does not strive for "what we expect" at all, but "reflects the condition measured by its denial". ${ }^{37}$ Despair itself, over the existing art world, the existing state of affairs, is transformed, Adorno argues, into transcendental ideas that "bridge" the gap between despairing and wishing. But isn't despair, in Bloch's words, that negative affective state, the negative affect of expectation that determines the defeatism of its mental state, as opposed to the positive affect of expectation (expectance), hope, which "wrecks fear, and confidence, which corresponds to despair". "Danger and faith are the truth of hope, in such a way that both are gathered in it, and danger contains no fear, faith no lazy quietism. Hope is thus ultimately a practical, a militant emotion, it unfurls banners. If confidence emerges from hope as well, then the expectant emotion which has become absolutely positive is present or as good as present, the opposite pole to despair". ${ }^{39}$ An emancipatory work of music would be a work, Adorno would say, that managed to express the situation of waiting in vain. Such a work of music would not imply the Hegelian philosophic-aesthetic essentialism of authenticity as that which emerges by overcoming the negation of the positive, the existing, a claim that made a significant impact on theoretical interpretations of Marx's positions toward the premise of art becoming life; such a work would be "alive" inasmuch as it would be realized as a mediation between individuals and society ${ }^{40}$ - a mediation of waiting for the Real in vain. For instance, the key segments of Alban Berg's opera Wozzeck are precisely those that, according to Adorno, express waiting in vain, such as deferral, as do the narrative openness and literary structure in Beckett's Waiting for Godot. Wozzeck, Adorno argues, expresses a tense retreat from its own starting position precisely at those moments when that position gains traction: "impulses of the work, alive in its musical atoms, rebel against the work that they produce. They tolerate no result". ${ }^{41}$ However, this experience of waiting in vain in music, as a specific innervation, is entirely unrelated to authentic life, because, according to Adorno, "nothing could be experienced as truly alive if something that

\footnotetext{
37 Theodor Adorno, Negative Dialectics, op. cit., 375.

38 Ernst Bloch, "More on the Expectant Emotions (Anxiety, Fear, Terror, Despair, Hope, Confidence) and the Waking Dream", in: The Principle of Hope. Volume One, Cambridge, MA, The MIT Press, 1996, 111.

39 Ibid., 112.

40 Stefan Köchel, "Vergebliches Warten", op. cit., 171.

41 Theodor Adorno, Philosophy of New Music, Minneapolis, University of Minnesota Press, 2006, 56.
} 
transcends life were not promised also". ${ }^{42}$ Music is supposed to express with its narrative and spatiotemporal extent that there is no ultimate salvation one could hope for; in this perspective, waiting in vain implies waiting for the truth of art, the truth of the Real, but always with the reservation that it is only yet to come, meaning that it is never already here. Waiting is nothing but an experience of time; it is basically a utopian experience of not having a place.

So, Adorno's essential position regarding the negative imperative of waiting in vain expressed in music, aesthetics, and philosophy, is "Auschwitz". It implies that something like that must happen never again and that music, among other things, must express that negative imperative. But what is the content of this negativity of a negative imperative? The answer lies in the unthinkability of the horror of the Real "Auschwitz" - in acting in the domain of music and art in line with what must never be repeated, which ultimately implies acting according to the principle of negating the negation of the positive. Therefore, Negative Dialectics implies that what is negative with regards to the positive must never turn into affirmation, into a totality, into something that one might, in Hegelian terms, overcome or transcend.

Pursuing Adorno's demand, Badiou seeks to examine the issue of affirmation as negation of the negative in "the case of Wagner", bearing in mind that one of the key traits of waiting in vain in music is expressed in the ideality of the open work - a work that must never reach its absolute, its finality, its own ending. But why use Wagner as an example, the example of every critique of Wagner's music, or, more precisely, of every critique of Wagnerism? Because the metaphysical problem of the Will and relating it to modernity, especially in the $20^{\text {th }}$ century, is explicitly stated in all critiques of Wagnerism, from Nietzsche via Heidegger and Adorno, to mention only the most explicit examples, to the critiques that Lacoue-Labarthes developed in their wake. The politics of the Will and its "essential" link with modernity is at the heart of all critiques of Wagner's music. The point is that in a certain sense, the very notion of waiting coincides with utopian Messianic waiting, which means with the problem that utopianism may transform into "bad science". 43

On the trail of Adorno's Versuch über Wagner, Badiou opposes Adorno's claim that Wagner's operas are unable to express "any genuine waiting", ${ }^{44}$ bear-

42 Theodor Adorno, Negative Dialectics, op. cit., 375.

43 Wesley Phillips, "The Metaphysics of Willing in the Case of Wagner", Waiting in Vain? Metaphysics, Modernity and Music in the Work of T. W. Adorno, Martin Heidegger and Luigi Nono, Middlesex University's Research Repository 2009, 58. http://eprints.mdx. ac.uk/11148/, accessed 4 June 2014, 13:56 PM.

44 Alain Badiou, "Reopening 'The Case of Wagner"”, in: Five Lessons on Wagner, London New York, Verso, 2010, 79. 
ing in mind Adorno's position that Wagner's expression of "waiting" in opera is one that is still "metaphysically oriented", given that it concerns waiting for the final result. Adorno argues that "Wagner's Bayreuth conception" of music rests on Hegelian absolute interest. Wagner's operas are incapable of dramatizing utopian modern waiting and instead express the expectation of evental fulfilment, Adorno claims. Besides implicating Wagnerism in Nazi ideology, Adorno accused Wagner's music of anticipating cultural industry. In Badiou's view, Adorno condemns Wagner's music, ${ }^{45}$ arguing that it expresses a rigged sort of waiting, which is deeply teleological in its "latent dialectical Hegelianism". 46

Badiou's critique of Adorno's opposition to Wagner's opera, which follows the philosophical line that, each in his own way, Nietzsche, Heidegger, and Lacoue-Labarthe also advanced, practically initiates a radical critique of Adorno's reference to, for instance, one of the main scenes, in Act III of Tristan und Isolde, when Tristan dies and Isolde finally arrives, arguing that the very act of Isolde's arrival demonstrates metaphysical expectation of the final. However, Badiou maintains that Wagner's opera truly expresses futile waiting - pure waiting in the very spatiotemporal structure of that example. In many segments of the opera, according to Badiou's interpretation, one may even detect a neglect of waiting in vain and emphasis on emptiness that is present in opposition to any kind of evocation of "final salvation" from Adorno's theoretical-philosophical perspective. ${ }^{47}$ Here, too, Badiou makes an extremely interesting and, in my view, rather important claim: in this particular situation, it is rather a case of a certain surplus of waiting, of exceeding waiting itself, because Isolde finally comes, but her arrival brings no "salvation" or "resolution" whatsoever to the conflicted, tragic situation, since Tristan dies anyway. Her arrival implies a type of waiting that exceeds waiting itself, when one is no longer, to use Jacques Lacan's terminology, in the field of the Other's desire, but on the other side of the pleasure principle, where the Will for pleasure in the desired object is evacuated. It is that domain of the relation of indifference that is established between the "principle" of happiness and the duty of individuals, as opposed to the void around which "pulsates" the death drive. ${ }^{48}$ Isn't this that surplus of waiting that

45 One must take care in interpreting Adorno's writings on Wagnerism, bearing in mind that his position is quite specific in regard to other critiques of Wagner's music. He does not necessarily assume a pro or contra stance regarding Wagner, but only subjects Wagner to critical analysis, as a "phenomenon" in the history of music.

46 Ibid., 120.

47 Ibid., 122.

48 Cf. Alenka Zupančić, Ethics of the Real: Kant and Lacan, London - New York, Verso, 2000 . 
turns into expectation, but not the expectation of the metaphysical presence of an event, but the chiliastic non-eschatological expectation of the formalization of an artistic act?

In Badiou's surprisingly different interpretation of Beckett's writing, especially concerning Waiting for Godot (En attendant Godot), as opposed to the one attributed to the epoch's existentialist perspective, Badiou emphasizes precisely the experience of loss, to put it more accurately, the disappearance of that which at the same moment, at the same place appeared as affirmation (as disappearing); that experience of an "error", "mistake", "lack", "failure" "demands" and drives individuals to act and enables the perception of a place at the border of a void (event), a place of the disappearing experience of the generic quality of the humanum. In Badiou's reading, Beckett demonstrates, similarly to Wagner, that the modern subject, at the most radical point of destitution, manages to turn around the given circumstances of an actual loss. ${ }^{49}$ And that is what Wagner's operas, especially Tristan and Isolde, offer in plentiful supply: Isolde's arrival implies no metaphysical fulfilment, end, resolution of the tragedy, because, to repeat, Tristan dies anyway, but an evocation of the experience of a lack as pure waiting, Badiou might say, as opposed to the passive dimension of waiting in vain. That experience of a lack implies neither passive disappointment over a (tragic) loss, nor the fullness of an experience of metaphysical salvation, but a surplus of waiting or waiting that exceeds itself, coming into the possession of aesthetic-political indifference.

Furthermore, an important trait of Wagner's music, Badiou notes, inheres in the very possibility of creating a perception of time, which is, as I showed above, nothing but the process of subjection itself, by citing three possible types of constructing time: a) the time of disparate worlds, or the time of wandering, as Badiou dubs it, which implies the process of transitioning from one world into another; b) the time of the period of uncertainty, which anticipates temporality "in between", meaning the creation of a utopian possibility that is always already not there; and, finally, c) the time of the tragic paradox. One should also note that Badiou defends Wagner's music in this segment, arguing that the duration times of his music are entirely unrelated to this possible reading of time in Wagner's operas. In fact, Wagner's music, regardless of duration, always introduces, with its spatiotemporal structuring, a new perception of time..$^{50}$

Although there are many indications of invoking a mere exposure of the

49 Chris Pawling, "Badiou and the Search for an Anti-Humanist Aesthetic", in: Critical Theory and Political Engagement: From May 1968 to the Arab Spring, New York, Palgrave Macmillan, 2013, 137.

50 Alain Badiou, "Reopening 'The Case of Wagner'”, op. cit., 123. 
Real of art, in other words, of aestheticizing politics in Wagner's operas, among which, as the most explicit charges, one should cite the role of myth in producing a construction of the origins of the German nation and the affirmation of total art (Gesamtkunstwerk) in terms of a mere bio-political shaping of life and the implication of this notion with Adorno's critically intoned cultural industry, Badiou cites several important trajectories for deconstructing the Messianic Will, which has been invoked against Wagner already since Nietzsche's polemics:

1. the realization of the possibility of a subject, by showing the way whereby this subject of art may appear, in Wagner's case, more closely connected to the very spatiotemporal process of performing music, Badiou argues, than to its accompanying narrative;

2. the multiplicity of hypotheses in Wagner's operas as opposed to the unification of a Single Goal or purpose, whereby this multiplicity of assumptions is revealed at the moment of hesitating between them;

3. the demonstration of the splitting of the subject, which in Wagner's music implies the presentness of an unresolvable division for which Wagner proposes a form (formalization of the act of splitting) and not form in terms of a final Hegelian reconciliation;

4. the principle of non-dialectic resolution, which Badiou identifies in Wagner's attempt "to find a decisive figure" that would neither bring music to an end, nor centrally impose on the work a unifying Idea from without. It is a kind of resolution that is always "on the alert" - which prefers to examine the truth of art than "blindly" to adhere to it. ${ }^{51}$ Such a resolution rests on undecidability, ${ }^{52}$ which implies that there is no calculation, measure, or assessment to enable deciding in favour of One, that is, the Ego: and, finally,

5. transformation without finality, in a way that the form of this transformation should be sought in the resources of transformation itself. ${ }^{53}$

\section{Waiting in Vain and Non-eschatological Chiliastic Expectation}

However, singular change in the field of art is not the same as absolute change, which is mostly interpreted by reference to the $20^{\text {th }}$ century "passion for the Real": the $20^{\text {th }}$ century "passion for the real was the passion to create a new

\footnotetext{
51 I should mention that Badiou distinguishes between three subject figures: the believing, reactive, and obscure subject - sujet fidèle, sujet réactif, and sujet obscur. The present text concerns the sujet fidèle.

52 Alain Badiou, Ethics: An Essay on the Understanding of Evil, London - New York, Verso, 2002, 54.

53 Alain Badiou, "Reopening 'The Case of Wagner"', op. cit., 131.
} 
world". ${ }^{54}$ The demand for change, for emancipation as the absolute in the domain of art, that is, music, as the $20^{\text {th }}$ century showed in a number of instances and as the beginning of the new millennium, with the consequences of the fall of the Berlin Wall, keeps showing, has produced numerous "deviant" perspectives, such as those that Walter Benjamin characterized with the concept of "aestheticization of politics" (the conjunctions of fascism and art, socialism and art, communism and art, formal democracy and human rights and art, etc.). For, the issue of negating the existing state of art, of the fetishized givens of the senses, of the facticity of art, is not a strictly Hegelian issue, to which Badiou, to put it bluntly, adhered during his "Maoist phase" 55 (the logic of contradiction, not difference), in other words, not dialectical materialism, but materialist dialectics.

Badiou's philosophy of event (in music) evokes the metaphysical problem of "waiting" (Warten) for the truth of an event for the sake of singular, emancipatory change in the domain of art (maturity of a situation), in other words, for the trace as requisite for the subjection process, bearing in mind that singular change depends on the split in the objective world. From this perspective, Badiou's affirmation of a new subject of art might be accused of "lazy quietism". For, the "threat" of the metaphysics of presence, as I argued above, almost inevitably coincides with the notion of waiting for something/anything (mere exposure of the Real), which goes hand in hand with the blind imperative of "destroying and purifying the Real of art" as a precondition for opening a rift or some other space in the existing state or world of art, as the starting point for reaching a "higher", "possible" level of (human) freedom. Accordingly, my intent, finally, is to try to answer what kind of waiting for human emancipation in the domain of art and music as well as what kind of emancipation of music from the existing world of art this is. My intent stems not from a need to argue necessarily "for or against" Badiou's theoretical perspective, which is extremely complex and rather heterogeneous, wherein I would locate the sheer difficulty of performing its reception and interpretation, but in a sense to "expand" Badiou's theoretical perspective and try to offer a new vector for thinking this problem. Finally, this question coincides with another serious problem in Badiou's aesthetics, which occupies, among other things, the entire volume two of Being and Event - the question of the mode of relation in the dialectic pair affirmation/negation, especially taking into account the defence of his thesis of emancipatory art as affirmative art.

There is a place where Badiou says that one should not seek to set as an imperative a "revival" of events such as the famous May '68, Schoenberg's do-

${ }^{54}$ Alain Badiou, The Subject of Change, op. cit., 116.

${ }^{5}$ Cf. Alain Badiou, Théorie du sujet, Paris, Éd. du Seuil, 1982. 
decaphony, etc., because any programmatic attempt at such a "revival" would lead into Terror, the politicization of aesthetics. On the other hand, he argues that the "best thing we can do" as individuals in the present state of a radical expansion of global corporate capitalism, the global hegemony of democratic materialism, and subjection of art to this imperative is "to create the intellectual and practical forms of minimal fidelity [fidélité] to the earlier sequence and to the revival of its novelty". 56 Therefore, Badiou, on the one hand, argues that it is necessary to "construct" a framework (discourse?) for receiving events-to-come or events that-perhaps-won't-come, in other words, to "prepare" (?) to receive the truth(s) of art as post-evental consequences. That somewhat approximates Foucault's mode of thinking practices as preparing to access the truth (epimeleia heautou). ${ }^{57}$ On the other hand, he argues that the power of individuals' actions, which means the power of subjections in the domain of art, depends exclusively on the emergence of this kind of artistic event/s in a particular world and on recognizing their traces-truths, because events may occur without individuals being "able" to "recognize" their truth/s. On the one hand, Badiou's starting point approximates the radical humanistic position, which is, at least concerning his interpretation of Beckett's play, inclined to think the emergence of a generic humanity, close to the Marxist humanism of Sartre, who, conditionally speaking, posits the subject as a project to be reached through a concrete process of emancipation, while on the other hand, he strives to remain faithful to post-Marxist anti-humanism, so that the realization of the subject of art depends entirely on unpredictable event/s. ${ }^{58}$ However, if the individual within a given world of art is "capable" of the practice of preparing for the truth, without any unpredictable event that would condition that preparation practice, I could argue, following Badiou's inaesthetic perspective, that precisely this practice of preparing a "framework" for recognizing the truth assumes the shape of pure waiting that exceeds itself. In other words, in line with this construction, the event of this new, emancipatory art is no "miracle" that may suddenly occur or that occurs and may give rise to a recognition of its consequences - in other words, the truth of subjection/s, but that event/s itself/themselves is/are break/s in the objective world, un-temporal non-beings, which are "always in their place" and which, as such, insert individuals into new chains of needs, desires, and drives for generic life. Events are therefore rare, instantaneous supplements of/within situations and introduce the new by establishing truth procedures.

\footnotetext{
56 Alain Badiou, "Thinking the Emergence of the Event", in: Cinema, Cambridge, MA, Polity Press, 2013, 110.

57 Michel Foucault, The Hermeneutics of the Subject: Lectures at the Collège de France, 1981-82, New York, Palgrave Macmillan, 2005, 29.

58 Alain Badiou, On Beckett, Manchester, Clinamen Press Limited, 2003, xxii.
} 
In this context, I should right away point to an important statement Badiou makes in Logics of Worlds, which appears to explain the problem of the paradoxical relation between the event and the subject: "only if the subject is there, the event may appear at the evental place" - a place that is always at the border of a void (an empty set / non-being / event). This statement points to an almost "common-sense" question: what comes "first", the event or the subject? The answer is that nothing comes "first". At its very basis, the question betrays the answer that it seeks. This concerns a certain logic of reversibility, whereby not only does the event condition the subject, but the subject also conditions the event. In other words, event/s cannot even "appear" by way of a trace without there being those rare individuals who will "recognize" those traces and begin a new artistic sequence of a subjective truth procedure. In yet other words, subjective cognition (subjection) of an event always occurs a posteriori: I come to know that there was an event, a rift in a given world, only after a subjective historical sequence has been "exhausted".

In this kind of thinking perspective, one may identify a distinction between waiting in vain in the sense of Adorno's concept and chiliastic non-eschatological expectation as pure waiting that exceeds itself. It concerns a creative surplus that is "always already there", a surplus of waiting (expecting) as a tense surge of time that may "awaken" singular events and the realization of a new artistic sequence in a given world. But this surge of time does not disappear through a simple negation of ordinary life, but through a reverse that has no connection whatsoever with a mere classical negation of the Hegelian type. In other words, in Badiou's theory of art, there may be a logic of negation within the phenomenal world, but not in the sense of the classical philosophy of negation and its transcendental condition. For, the concept of negation, as Badiou sees it, entails rather a reverse, whose "only common ground" with the classical concept of negation is that being-there and its reverse in the same world do not have "anything in common (the conjunction of their degrees of intensity is nil)". 59 Following Deleuze, or, rather, Badiou's reading of Deleuze, one might call this disjunctive synthesis. ${ }^{60}$

Accordingly, thinking the appearance of negation, which is another name for Badiou's conception of artistic truth, along the lines of early Marx, should be sought in Badiou's ontology of subtraction, which implies a "new type of dialectics" - in materialist dialectics. If Badiou defines the present global state of affairs with hegemonic democratic materialism, which, as the official global

59 Alain Badiou, Logics of Worlds, op. cit., 107.

${ }^{60}$ Cf. Jean-Jacques Lecercle, "Disjunctive Synthesis", in: Badiou and Deleuze Read Literature, Edinburgh, Edinburgh University Press, 2010, 6-38. 
ideology, also subsumes art and thereby prevents emancipation through, including in art, and which says that there is only "Two", that is, the "sovereignty of language and the body", then one may juxtapose it with materialist dialectics, where, instead of the essentialist Hegelian "reconciliation and overcoming" of a contradiction, one could think this Third Pole as "excess", a "supplement" or "complement of the reality of Two": "there are only bodies and languages, except that there are truths". ${ }^{61}$ It is that creative surplus that moves "in the direction of the intensity of life, a 'limitless gift', a 'greatness', 'clear flames woven into living chimeras". 62 An artistic, avant-garde rebellion, says Badiou, "means that within the extremity experienced in negative excess abides the certainty that we can change its sign".63

In that sense, chiliastic non-eschatological expectation, in my view, does not incline toward a passive Adornian negation of negation (the affect of despair), or to the transcendental metaphysical experience of awaiting the absolute (an absolute affirmation of authentic humanity / exposure of the Real), but, rather, to the process of transforming a negative surplus into an affirmative surplus - the transformation of the (tragic) experience of loss, of a lack, as I demonstrated regarding Badiou's interpretation of Wagner's operas, into an endless rebellion capable of performing the operation of a reversal. Avant-garde, tense chiliastic expectation operates by experimenting with the future in the present, hic et nunc, concretizing, although always already "failing", the promise of the generic human. Precisely due to this failing, an emancipatory operation is never without a remainder. A negative remainder implies "failure", but not in terms of the passive affect of disappointment, fear, despair, or angst over the affirmative disappearance of the chiliastic process of subjection. Rather, I would interpret the "surplus of waiting" in terms of the affect of hope, which may not be equated either with the negative affects of waiting (vergebliches Warten) or with disposition as such, and would therefore lead to "new chains" of expectation. In my view, Adorno's vergebliches Warten inclines toward the affect of despair, that, by all accounts, filled affect, which, due to its own fullness, leaves no space-time for the new, for human emancipation in the domain of music/art. It expresses the defeatism of the known, i.e. "perseverance-of-self" (suum esse conservere), as Badiou might say, echoing Spinoza.

I propose, as a concept, the practice of non-eschatological, activated, tense, anticipating chiliastic expectation, which would rely neither on the filled affects of despair, fear, angst, or disappointment over the unthinkable (Auschwitz), nor

61 Alain Badiou, Logics of Worlds, op. cit., 4.

${ }^{62}$ Alain Badiou, The Century, op. cit., 142.

63 Ibid., 143. 
on the practices of remembrance, memory, or nostalgia, which typically assume the form of regurgitating existing texts of culture in a self-satisfying play of historical illusions and allusions, in other words, neither on waiting that expects nothing, nor on waiting that expects something, nor on waiting in vain, nor on waiting as the Will, but the practice of preparing (surplus of waiting) for singular change in the domain of music, to receive the truth in art. 